\title{
15 Recent Changes in the Modal Area of Necessity and Obligation - A Contrastive Perspective $^{1}$
}

\author{
Karin Aijmer \\ University of Gothenburg
}

\section{Introduction}

Recently we have witnessed a lively discussion about modal changes in contemporary English. Leech et al. (2009) have for instance shown, on the basis of corpora from different periods, that the modal auxiliaries in general and must in particular have declined in frequency over the relatively short period between I960 and I990. The changes affect both the epistemic and deontic meaning but have been particularly drastic for deontic must.

There are still many questions in the air; for example what do speakers use to compensate for the loss of the modal auxiliary (if anything). This question has given rise to the hypothesis that the disappearance of must is counterbalanced by the emergence and growth in the frequency of other modal elements in particular semi-modals. However the range of alternatives which have been studied has been fairly restricted.

The aim of my paper is to contribute to the discussion of the decline of the modal auxiliary must by a comparison with its Swedish cognate maste which has not undergone the same semantic developments. We can study both when must is chosen as a translation and when a different lexical item or construction is preferred. This approach can provide a rich panorama of expressions of obligation and necessity. Translations can also confirm hypotheses which have been suggested on the basis of monolingual corpora.

The structure of my paper is as follows. I will first discuss my methodology and the use of a parallel or translation corpus. I will then

${ }^{I}$ With many thanks to Bengt Altenberg for excellent comments on an earlier version of the article

How to cite this book chapter:

Aijmer, K. 20I5. Recent Changes in the Modal Area of Necessity and Obligation - A Contrastive Perspective. In: Shaw, P., Erman, B., Melchers, G. and Sundkvist, P. (eds) From Clerks to Corpora: essays on the English language yesterday and today. Pp. 267-284. Stockholm: Stockholm University Press. DOI: http://dx.doi.org/IO.I6993/bab.o License: CC-BY. 
analyse the translation paradigms with must and alternative realisations of obligation or necessity. The translations will also provide the raw material for a qualitative analysis contrasting the functions of must and its most frequent competitors. I will then compare the translation paradigms in fiction and non-fiction texts in order to look for text-type specific differences. My paper will end with a summary and a discussion of the advantages of using data from a parallel corpus.

\section{Methodology}

The data for the present study are taken from the English-Swedish Parallel Corpus (ESPC) (see Altenberg and Aijmer 200I). The corpus contains roughly comparable original texts in English and Swedish with their translations, altogether 2.8 million words. The Swedish and English texts have the same size and represent the same genres namely fiction and non-fiction texts. (see Table I).

The relationship between masste or must in the original texts and their correspondences in the target texts can be exhibited as a translation paradigm showing how often must and måste correspond to each other in translation. The translations also show what the alternatives are when must and måste are not translated into each other.

\section{The frequency of must and of måste}

I became interested in the on-going restructuring of the English modality system through the observation that English must seemed to be much less frequent in English than its cognate måste in Swedish. There were 544 examples of must in the English originals in the corpus. There were more than twice as many examples of måste in the Swedish original texts (I IO4 examples). The difference in frequency is found both in fiction and non-fiction (See Table 2).

The smaller number of examples of must in the English original texts compared with Swedish måste is interesting against the background of

Table 1. Size of the English-Swedish Parallel Corpus.

Number of words

\begin{tabular}{ll}
\hline Fiction & I,328,929 \\
Non-fiction & I,475,582 \\
Total & $2,804,5$ I I \\
\hline
\end{tabular}


Table 2. Must and maiste in the English and Swedish original texts. Normalized figures to Io, 000 words in parentheses.

\begin{tabular}{lcc}
\hline & English originals ('must') & Swedish originals ('måste') \\
\hline Fiction & $2 \mathrm{IO}(\mathrm{I} .58)$ & $454(3.42)$ \\
Non-fiction & $334(2.26)$ & $650(4.4 \mathrm{I})$ \\
Total & $544(\mathrm{I} .94)$ & $\mathrm{I}$ IO4 $(3.4)$ \\
\hline
\end{tabular}

what has been claimed about the decline of must in English and the emergence of competing variants.

The English-Swedish Parallel Corpus is designed as a bidirectional corpus which can be used to study translations between languages in two translation directions:

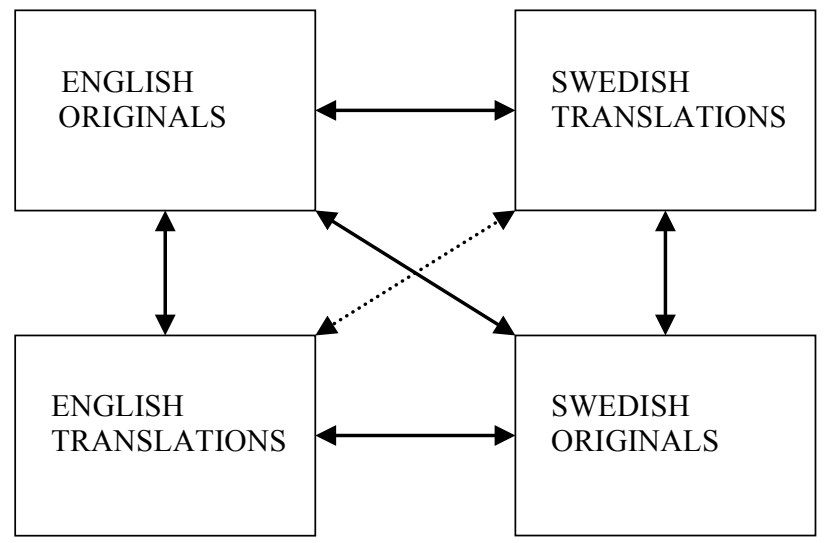

Figure 1. The structure of the English-Swedish Parallel Corpus.

We can therefore use the corpus to test the hypothesis that must is disappearing in the translation. Must and måste are cognates and 'favoured' correspondences in a translation perspective. According to Gutknecht and Rölle (I996: 237), 'modals should preferably be rendered by modals, because they correspond to each other in terms of various kinds of non-specificity.' If must is avoided in the translation this may therefore suggest that it is losing out in the competition with other grammaticalizing elements.

Correspondences between languages can be established by studying translations and sources. If must is in the process of disappearing we would also expect it to be less frequent in English sources of måste (going from Swedish translations to English originals). 


\section{Epistemic and deontic must}

At the outset, a distinction needs to be made between deontic and epistemic meanings of must. Epistemic meaning has been defined in terms of a judgment by the speaker: 'a proposition is judged to be uncertain or probable in relation to some judgment' (van der Auwera and Plungian I998: 8I).

With must the speaker represents a situation as relatively certain:

I. “That's Davina Flory.” I guessed it must be," Burden said quietly. $(\mathrm{RR} I)$

Must can also be deontic. Deontic modality "identifies the enabling or competing circumstances external to the participant as some person(s), often the speaker, and/or some social or ethical norm(s) permitting or obliging the participant to engage in the state of affairs" (van der Auwera and Plungian I998: 8I).

2. I put a finger to his mouth: "Don't bring it up again. You must allow me this chance in Provence to make up my mind." (BRI)

\subsection{Epistemic meaning}

The epistemic meanings of must are generally infrequent. Only io9 examples $(25 \%)$ of the examples of måste (454 examples) were epistemic and $328(75 \%)$ deontic. Moreover when we compare Swedish maste in the epistemic meaning and English must we find a fairly high correspondence (Table 3 ).

Must dominated in the translations of Swedish epistemic måste $(78.9 \%)$ and in the sources $(83.5 \%)$. The mutual correspondence between måste and must (based on the translations in both directions) is $8 \mathrm{I} .2 \% .^{2}$ Epistemic must seems to be stable. In diachronic terms it is not threatened by semi-modals which belong to the area of deontic modality (have got to was only found three times). (See further below.) In non-fiction texts (not shown in the table) epistemic must was even more infrequent than in fiction ( 24 examples) and the translations did not contain any alternatives.

The translations consist of modal auxiliaries (besides must) such as could, might, will, would. Other alternatives are adverbs (obviously,

${ }^{2}$ Mutual correspondence refers to 'the frequency with which different (grammatical, semantic and lexical) expressions are translated into each other (Altenberg I999: 254). 
Table 3. The English Translations (SO->ET) and sources of Swedish måste $(\mathrm{ST}<-\mathrm{EO})$. Epistemic meanings. Fiction only.

\begin{tabular}{|c|c|c|c|}
\hline Translation & Correspondence & Sources & Total \\
\hline must & $86(78.9 \%)$ & $9 \mathrm{I}(83.5 \%)$ & $\operatorname{I} 77(8 \mathrm{I} .2 \%)$ \\
\hline surely & $\circ$ & 5 & 5 \\
\hline would (maybe) & I & 3 & 4 \\
\hline have got to & 2 & I & 3 \\
\hline (you) can be sure & 2 & ० & 2 \\
\hline could (perhaps) & 2 & ० & 2 \\
\hline will & ० & 2 & 2 \\
\hline I suppose & I & ० & I \\
\hline maybe & I & ० & I \\
\hline presumably & I & ० & I \\
\hline obviously & I & ० & I \\
\hline perhaps would & I & ० & I \\
\hline doubtless & I & ० & I \\
\hline sounds like & I & ० & I \\
\hline might & I & ० & I \\
\hline must surely & I & ० & I \\
\hline may & ० & I & I \\
\hline of course & o & I & I \\
\hline I suppose & O & I & I \\
\hline it is certain to & o & I & I \\
\hline omission & 6 & ० & 6 \\
\hline other & I & 2 & 3 \\
\hline Total & I09 & I09 & $2 I I$ \\
\hline
\end{tabular}

presumably, doubtless, maybe, perhaps) or verbs and adjectives (you can be sure, I suppose, sounds like).

\subsection{Deontic modality}

Deontic modality (obligation/necessity) is a more complex semantic field than epistemic modality. As shown by its translations deontic must has many competitors or what Leech et al. (2009) describe in diachronic terms as the present-day beneficiaries of must's decline. For this reason I will focus on the deontic must and its competitors in the domain of obligation and necessity (Table 4 ). 
Table 4. The English translations and sources of Swedish måste (SO ->ET and $\mathrm{ST}<-\mathrm{EO})$. Deontic meanings. Fiction only.

\begin{tabular}{|c|c|c|c|}
\hline Correspondence & Translations & Sources & Total \\
\hline have to & $9 \mathrm{I}(27.7 \%)$ & $9 \mathrm{I}(30.5 \%)$ & I $82(29.1 \%)$ \\
\hline had to & $9 \mathrm{I}(27.7 \%)$ & $8 \mathrm{I}(27.2 \%)$ & $\operatorname{I72}(27.5 \%)$ \\
\hline must & $78(23.8 \%)$ & $38(\mathrm{I} 2.6 \%)$ & I I $6($ I $8.5 \%)$ \\
\hline (have) got to & I $4(4 \cdot 3 \%)$ & I9 $(6.4 \%)$ & $33(5.3 \%)$ \\
\hline need to & 8 & 9 & I7 \\
\hline should & 5 & 3 & 8 \\
\hline need (main verb) & 2 & 4 & 6 \\
\hline will/would & 2 & 4 & 6 \\
\hline is to/was to & 4 & I & 5 \\
\hline ought to & 4 & $\circ$ & 4 \\
\hline imperative & $\mathrm{I}$ & 3 & 4 \\
\hline be going to & I & 2 & 3 \\
\hline had better & 2 & I & 3 \\
\hline make sb do sth & 3 & ० & 3 \\
\hline it meant -ing & ० & 3 & 3 \\
\hline be due to & I & I & 2 \\
\hline NP modification & ० & 2 & 2 \\
\hline formulaic & o & 2 & 2 \\
\hline can't wait to & o & 2 & 2 \\
\hline be in need of & I & ० & I \\
\hline be expected to & I & $\circ$ & I \\
\hline it was natural for $\mathrm{X}$ to & I & ० & I \\
\hline couldn't possibly & I & $\circ$ & I \\
\hline necessarily & I & ० & I \\
\hline past tense & I & ० & I \\
\hline could not help & I & ० & I \\
\hline $\begin{array}{l}\text { it does not necessarily } \\
\text { follow that }\end{array}$ & I & ० & I \\
\hline emphatic do & I & ० & I \\
\hline it's time & $\mathrm{I}$ & ० & I \\
\hline be required & ० & $\mathrm{I}$ & I \\
\hline want & ० & I & I \\
\hline be forced to & o & I & I \\
\hline
\end{tabular}


Table 4. Continued

\begin{tabular}{lccc}
\hline Correspondence & Translations & Sources & Total \\
\hline inevitably & 0 & I & I \\
know to do something & 0 & I & I \\
be obliged to & 0 & I & I \\
I don't mind & 0 & I & I \\
could only & 0 & I & I \\
omission & 4 & I & 5 \\
other & 7 & 23 & 30 \\
Total & 328 & 298 & 626 \\
\hline
\end{tabular}

The percentages are based on 328 examples in the translations and 298 examples in the sources. In all there were 39 different translation alternatives. There is a low degree of mutual correspondence between masste and must. The mutual correspondence of must was I $8.5 \%$ to be compared with have to which had a mutual correspondence of $29.1 \%$. The higher frequency of must in the English translations than in sources may be induced by the high frequency of 'måste' in the Swedish original; cf Johansson (2007: 32-33) a 'translation effect'. The translator uses a cognate even when a more 'idiomatic' translation is available. Have to was used in translations $(27.7 \%)$ and in sources $(30.5 \%)$. The frequency of have to would have been even higher if I had included had to. However had to has been used as an alternative of must for syntactic reasons. It was used in roughly $23 \%$ of the examples (both in translations and sources) as a past tense form mainly in narrative contexts. Had better is associated with weaker obligation than have to and it only occurred three times as a correspondence. Need to was more frequent than should but not as frequent as have got to.

The translations draw attention to the fact that must has a large number of co-players in the domain of obligation/necessity. Many different grammatical categories are represented in the translations (see Table 5).

Other modal auxiliaries than must are should, ought to, will/would. A difference between English and Swedish is that English can express deontic modality by means of semi-modals. " "Semi-modals" are not full modals but are verb constructions (...) which have been moving along the path of grammaticalization and have gradually acquired an 
Table 5. Grammatical categories of deontic modality.

\begin{tabular}{ll}
\hline $\begin{array}{l}\text { modal auxiliaries } \\
\text { semi-modals }\end{array}$ & $\begin{array}{l}\text { must, should, ought to, will/would } \\
\text { have to, need to, have got to, be to, be } \\
\text { due to, had better }\end{array}$ \\
modal adverbs & necessarily, inevitably \\
modal adjectives & it was natural for X to \\
modal nouns & be in need of \\
lexical verbs & be required, be forced to, be obliged to \\
idioms & I cannot wait to do, I don't mind doing \\
imperative & let us VP \\
NP modification & three points to consider \\
emphasis & emphatic do, prosodic stress \\
\hline
\end{tabular}

auxiliary-like function' (Leech et al. 2009: 9I). The semi-modals with the meaning of obligation/ necessity mostly contain have. Have to, have got to, had better are all semi-modals. Less frequent semi-modals are be to, be due to. In addition we find modal adjectives and adverbs (it was natural for $X$ to, necessarily, inevitably), verbo-nominal expressions of modality (be in need of), lexical verbs (be obliged, forced, compelled). More idiomatic translations are for example I cannot wait to do. The deontic must also shares directional force with the imperative as shown by the translations. Three points to consider can be paraphrased 'three points which need to or must be considered'. The translation is an example of NP modification. There is also a close association between deontic modality and emphasis.

\subsection{Summing up deontic modality in fiction}

Grammaticalization and change are lurking in the background when we interpret the translation correspondences. The frequency of a certain translation can reflect its status as a 'substitute' of the declining must. In view of the diachronic findings about the decline of must it is not surprising that have to is more frequent than must in translation. The increase of have to in fiction is remarkable compared to other studies. Biber et al. (I999: 489) have compared the frequencies of modals and semi-modals in different registers. Must and have to had the same frequency in fiction but have to was more frequent in the conversational data. 


\subsection{Competition between must and have to}

The translation paradigms only provide the raw material for the semantic analysis. The meanings range from strong obligation or necessity (represented by must and have to) to weaker elements such as should or need to. Have to and must differ semantically. Have to (unlike must) refers to what van der Auwera and Plungian (I998:8I) have described as participant-external necessity. Participant-external necessity makes reference to the circumstances that are external to the participants and make a state of affairs necessary.

3. För att hålla mig igång krävs inte mer än ett par 1,5 volts fickbatterier. Jag omsätter samma mängd energi som en 20-wattslampa. Vattenlösningen, som jag vilar i, måste vara helt steril. (PCJI)

To keep me going requires nothing but a couple of I.5-volt batteries. I consume no more energy than a 20 -watt bulb. The aqueous solution in which I rest has to be absolutely sterile. (PCJIT)

In this example the source is clearly not the speaker but the properties of the aqueous solution.

If must is declining and have to is increasing in frequency we would expect the boundaries between them to be drawn up differently. The translations can be the basis for a deeper and more detailed analysis of the variation between have to and must. A factor such as the person of the subject has the advantage that it can be compared in the translations.

In the English Swedish Parallel Corpus have to was more frequent than must with an impersonal subject (e.g. generic you) than with the 'direct' you. It was also frequent with we as the subject (collective we)

Table 6. Variation between have to and must with different subjects.

\begin{tabular}{lrc}
\hline Type of subject & must & have to \\
\hline I & 44 & 28 \\
you generic & 4 & 37 \\
you direct & I9 & I I \\
animate subject & 32 & 44 \\
we collective & 8 & I7 \\
non-animate subject & 4 & I3 \\
passive & 2 & I 5 \\
\hline
\end{tabular}


or with the passive. Must on the other hand was more frequent with a first person subject and with the 'direct' you (Table 6).

The use of have to with a generic subject is illustrated in the following example:

4. Man måste lära sig ta skydd. (JMYI )

You have to learn how to take cover. (JMIT)

We can also be used impersonally:

5. Nu när det är krig måste man hjälpa varandra. (JMYI)

"Now that the war is on we have to help each other." (JMYIT)

Have to is used in an abstract way to make a recommendation (if something is favourable) or an instruction formulated in general terms.

The following example illustrates that must can have a strong emotional meaning urging the hearer to do something. According to Smith (2003: 259) such insistence can however sound odd in present-day English: 'Even where MUST is used with no obvious hint of speaker-imposed deontic meaning. ..., in Present Day English it is liable to be perceived as off, perhaps because it sounds unduly insistent'.

6. Ja, faster måste förstå mej: det är en ära att få arbeta ihop med ett sånt snille. $(\mathrm{ARPI})$

"Yes. You must understand me, Auntie. It's an honour to be allowed to work with such a genius." (ARPIT)

Moreover have to unlike must can be softened and is therefore used when more politeness is required:

7. Då måste du stanna hemma från skolan och passa henne. (GTI)

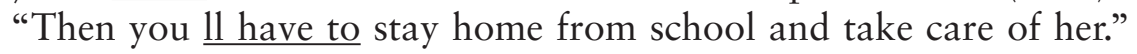
(GTIT)

8. Då måste jag sätta mig hos ålen. (KEI)

Then I'll have to sit with the eel. (KEIT)

Other examples of softening are illustrated by would have to and might have to (mitigating an inconvenience): The speaker's staying for a month may involve an inconvenience for the hearer:

9. Kanske måste jag stanna hos er en hel månad. (KOBI)

"I might have to stay with you for a whole month." (KOBIT) 
Checking in with the concierge involves some extra effort for the visitor:

IO. A visitor would have to check in with the concierge. (FFI)

En besökare måste anmäla sig hos portvakten. (FFIT)

\section{Non-fiction translations}

By including non-fiction in the study of must and its competitors we can get a more detailed and richer picture of the expressions of obligation and necessity. The number of examples is higher in non-fiction than in fiction texts. There were 526 examples in translation of måste and $4 \mathrm{I} 2$ examples in sources (deontic examples only). There were $4 \mathrm{I}$ different competing forms (most of them occurring only once or twice). See Table 7:

Table 7. English translations and sources of Swedish 'måste'.

\begin{tabular}{|c|c|c|c|}
\hline Correspondence & Translations & Sources & Total \\
\hline must & $295(56 \%)$ & I $77(43 \%)$ & $472(50.3 \%)$ \\
\hline have to & $63(12 \%)$ & $\operatorname{IOO}(24 \cdot 3 \%)$ & I63 (I7.4\%) \\
\hline need to & $27(5.1 \%)$ & 47 (I I.4\%) & $74(7.9 \%)$ \\
\hline should & $48(9.1 \%)$ & I $6(3.9 \%)$ & $64(6.8 \%)$ \\
\hline had to & $\mathrm{I} 7(3.2 \%)$ & $44(\mathrm{I} 0.7 \%)$ & $6 \mathrm{I}(6.5 \%)$ \\
\hline need main verb & 7 & 5 & I 2 \\
\hline mean V-ing & I & 5 & 6 \\
\hline ought to & 4 & I & 5 \\
\hline to be -ed & 4 & ० & 4 \\
\hline require & 3 & ० & 3 \\
\hline it is necessary & 2 & I & 3 \\
\hline to-modification & I & 2 & 3 \\
\hline would & 2 & I & 3 \\
\hline oblige to & I & 2 & 3 \\
\hline have got to & I & 2 & 3 \\
\hline was made to & 2 & ० & 2 \\
\hline will inevitably & 2 & ० & 2 \\
\hline (what may happen is) for $\mathrm{X}$ to $\mathrm{V}$ & 2 & ○ & 2 \\
\hline it is essential & 2 & ○ & 2 \\
\hline
\end{tabular}


Table 7. Continued

\begin{tabular}{|c|c|c|c|}
\hline Correspondence & Translations & Sources & Total \\
\hline will be to & I & I & 2 \\
\hline should like to & 2 & ० & 2 \\
\hline be bound to & ० & 2 & 2 \\
\hline was compelled to & I & ० & I \\
\hline I have no choice but & I & ० & I \\
\hline I cannot help but & I & ० & I \\
\hline agree on the need to & I & o & I \\
\hline appreciate the need to & I & ० & I \\
\hline be of the need to & I & ० & I \\
\hline to be compelled to & I & ० & I \\
\hline I would note & ○ & I & I \\
\hline subject to & ० & I & I \\
\hline was to & ० & I & I \\
\hline entail the need & ○ & I & I \\
\hline I regret to say & ० & I & I \\
\hline I'm sorry to tell you & ○ & I & I \\
\hline embarrassed to speak to me & ० & I & I \\
\hline forced to & ○ & I & I \\
\hline recognize the necessity of & ० & I & I \\
\hline necessarily & ० & I & I \\
\hline other & I 6 & 25 & $4^{\mathrm{I}}$ \\
\hline$\varnothing$ & I I & 2 & I3 \\
\hline total & 526 & $4 \mathrm{I} 2$ & 938 \\
\hline
\end{tabular}

Måste was translated into 'must' in $56 \%$ of the examples and in the examples with English sources it was found in $50.3 \%$ of the examples. Have to was chosen less often. Need to and should are also among the most frequent correspondences. It is interesting to make comparisons with fiction where the percentages of the most frequent variants are quite different. The ranking of the most frequent variants in fiction and non-fiction is shown in Table 8 (percentages only).

Must was more frequent both in translations and in sources in non-fiction reflecting the fact that must has not declined in frequency to the same extent as in fiction. Have to, on the other hand is less frequent in non-fiction where it is ranked below must. Had to is more frequent 
Table 8. Ranking of the most frequent variants in fiction and non-fiction texts.

\begin{tabular}{lcc}
\hline & Non-fiction & Fiction \\
\hline must & $50.3 \%$ & I $8.5 \%$ \\
have to & $\mathrm{I} 7.4 \%$ & $29 . \mathrm{I} \%$ \\
need to & $7.9 \%$ & $\mathrm{I} 7(2.7 \%)$ \\
should & $6.8 \%$ & $8(\mathrm{I} .3 \%)$ \\
had to & $6.5 \%$ & $27.5 \%$ \\
(have) got to & 0.32 & $5.3 \%$ \\
\hline
\end{tabular}

in fiction reflecting the fact that it is associated with narrative contexts. Have got to (gotta) was rare in non-fiction. On the other hand. need to, should (and ought to) were strikingly more frequent in non-fiction than in fiction.

\subsection{Text-type specific correspondences}

Certain correspondences are text-type specific. Have to, need to and should function as rhetorical devices in non-fiction texts (for example EU regulations) imposing an obligation also when no specific individual is mentioned. The following example uses have to (and must).

I I. Den andra faktorn är att vi måste se till att skaffa en utbildning som går att använda under lång tid när vi skaffar oss en utbildning. Det måste vara en bred grundutbildning, eftersom samhället förändras i allt snabbare takt. Det går inte att ha snabba utbildningar. Vidare måste det också vara ett livslångt lärande. (EANDI)

The other factor is that we must ensure that when we obtain an education we obtain one which can be used for a long time. There has to be a broad basic education, because society is changing ever more rapidly. It is not possible to have a quick education. Furthermore, there has to also be life-long learning. (EANDIT)

The reference is to a situation in the future when have to is used. The speaker envisages a broad basic education for everyone. The obligation is only weak since no individual is under the obligation to do something. Must in the same sentence implies greater imposition (we must ensure that we obtain a broad discussion even in the face of resistance).

Should is weaker than have to or must. It merely expresses that the situation referred to is favourable to the speaker, the hearer or to people in general: 
I2. Det viktigaste måste väl ändå vara Sveriges ekonomi och dess förmåga att kunna 'platsa' i sällskapet när det gäller inflation, räntevillkor osv. (EANDI)

The most important aspects should still be Sweden's economy and its eligibility for a place in the club in terms of inflation, interest rates and so on. (EANDIT)

When should and stronger deontic forms are used in the same context they overlap semantically. The ordering between must and should could be changed without any difference in meaning:

I3. Särskild vikt måste läggas vid tidig förvarning och tidigt agerande i konfliktlösning. Förebyggande diplomati måste ytterligare stärkas. (LHWI)

There must be a particular focus on early warning and early action in conflict resolution. Preventive diplomacy should be further strengthened. (LHWIT)

Need to is particularly frequent in non-fiction texts. However it is not used with its basic meaning of internal necessity or compulsion but in a more abstract sense imposing an obligation on a non-specific individual. Because of its basic meaning need to ('having a need') is especially appropriate to express that something is a desirable goal or in the hearer's best interest. Like should and have to it was frequent with the collective we or with a following passive. The combination we need to was used as a correspondence (as a translation and as a source) in 34 examples or almost half of the examples of need to (also when the Swedish original did not contain 'we') and need with a following passive verb in 25 examples. When the subject was not we it was for instance 'Countries of the European Union' or 'Swedes living and working abroad'. Leech et al. (2009: III) emphasise the strategic or manipulative function of need to: 'Here a double mitigation of imperative force occurs: not only is obligation represented as in the best interests of 'us', but by referring to 'we' rather than 'you' as the people with the need, the writer imposes a collective obligation on an often rather vague community of people including the addresser and the addressees'. ${ }^{3}$

3 Nokkonen (2006: 48) also points out cases where 'we need' is used in an impersonal, 'strong' way. She finds examples of this use in informative genres in the FLOB corpus. 
I4. Det måste bli en omprövning av de traditionella attityderna gentemot äldre och de roller som man vill ge dem. Speciellt gäller detta på arbetsmarknadsområdet. (EISCI)

We need to review our traditional attitudes towards senior citizens and rethink the roles we expect them to play in society. This applies particularly to the world of work. (EISCIT)

Rather than saying 'you must' (which is strongly impositive), the more polite we need to is used strategically as a way of urging an individual or the community in general to do something.

With a passive following need and a third person subject no direct reference is made to the speaker and hearer:

I 5. Flexibiliteten för medlemsstaterna måste matchas av en grupp indikatorer som skall identifiera behovet. (EMCCIT)

The flexibility for Member States needs to be matched by a range of indicators to identify need. (EMCCI)

The use of need conveys that the action (matching the flexibility of EU member states by certain criteria) is judged to be favourable (needs to be done). The imposition is only expressed weakly since it is not directed to a special individual.

There is a great deal of overlap between need to and other markers as indicated by examples where they are used in the same neighbourhood:

I6. Alla bidrag för att nå Kyotomålen måste användas, men man måste också ha deras inbördes relationer klara för sig;. (EVIRI)

Maximum efforts should be made to meet the Kyoto targets, but we still need to keep a sense of proportion.

Should and need are used in a similar way. Their ordering can therefore be exchanged without a difference in meaning.

\section{Conclusion}

The present study can be seen as a complement to comparative historical corpus studies of must and its changes over time. The developments and changes in the area of modality which have taken place between I960 and I990 are at least to some extent visible in translations. Translations can therefore confirm observations which have been made on the basis of monolingual corpora about the decline of must and the emergence of semi-modals and other variants.

- The translations confirm the observation that must has declined above all in the area of deontic modality 
- The translations also confirm the hypothesis that semi-modals are becoming more frequent to fill the gap left by must

- The translations also confirm the proposal that other modal auxiliaries such as need to and should compete with must and have to

The translations also showed that:

- must was more frequent than have to in non-fiction suggesting that the decline of must has made less progress there

- should/ought to and need were more frequent in non-fiction than in fiction

- have got to was infrequent in non-fiction

Translations also have certain advantages over monolingual corpora. In a monolingual corpus the range of forms with obligation/necessity meanings competing with must is not apparent. Monolingual studies have mainly discussed the rivalry between must and a few selected semi-modals.

Translations on the other hand provide a large number of variants of must. They may therefore add something to the picture of who the players are in the semantic domain of obligation and necessity. As an extra bonus they can also contribute to the discussion of the factors motivating the choice of a particular form. Leech et al. (2009: I I4) used the term 'ecology' to capture the idea that each form [in the same field of meaning] 'evolves its own niche in the expression of modality, expanding, contracting or maintaining its "habitat" in relation to other, partially competing, forms'. The translations show that obligation and necessity can be expressed in many different ways and that there are conventions for how the different forms are used. In fiction have to (unlike must) was generally used with generic or impersonal subjects to make recommendations or to give instructions. The area of semantic overlap between must and have to is therefore restricted to certain contexts. Have to was used as a mitigator unlike must which was insistent and emotional.

In non-fiction texts have to, should and need to were typically used as rhetorical strategies when the speaker addresses a vague community of individuals. They were for instance used with a similar function in contexts with the passive or we as the subject. However the high frequency of need to and should may also have to do with their basic meaning to refer to what is beneficial or the right thing to do. 


\section{References}

Primary sources:

Fiction -Swedish originals

ARPI Pettersson, Allan Rune, Frankenstein's faster-igen. Stockholm I989.

GTI Tunström, Göran, Juloratoriet. Stockholm I983.

$\mathrm{HM}_{2}$ Mankell, Henning, Den vita lejoninnan. Stockholm I993.

KEI Ekman, Kerstin, Händelser vid vatten. Stockholm 1993.

KOBI Bornemark, Kjell-Olof, Handgången man. Stockholm 1986.

MS I Scherer, Maria, Kejsarvalsen. Stockholm I983.

Fiction -English originals

BRI Brink, André, The wall of the plague. London I984.

FFI Forsyth, Frederick, The fourth protocol. London 1984

RRI Rendell, Ruth, Kissing the gunner's daughter. London 1992.

Non-fiction-Swedish translator/author

EANDI Europaparlamentets överläggningar.

EISCI Europaparlamentets överläggningar.

\section{Secondary sources:}

Altenberg. B. (I999). Adverbial connectors in English and Swedish: Semantic and lexical correspondences. In Hasselgård, H. \& S. Oksefjell (eds) Out of Corpora. Studies in Honour of Stig Johansson. Amsterdam and Atlanta, GA: Rodopi, 249-268.

Altenberg, B. \& K. Aijmer. (200I). The English-Swedish Parallel Corpus: A resource for contrastive research and translation studies. Mair, C. \& M. Hundt (eds) Corpus Linguistics and Linguistic Theory. Papers from the 2oth International Conference on English Language Research on Computerized Corpora (ICAME 20), Freiburg im Breisgau I999. Amsterdam and Atlanta, GA: Rodopi, I 5-33.

Biber, D., S. Johansson \& G. Leech. (I 999). Longman Grammar of Spoken and Written English. London: Longman.

Gutknecht, C. \& L.J. Rölle. (I996). Translating by Factors. New York: State University of New York Press.

Johansson, S. (2007). Seeing Through Multilingual Corpora. On the Use of Corpora in Contrastive Studies. Amsterdam/Philadelphia: John Benjamins. 
Leech, G., M. Hundt, C. Mair,. \& N. Smith. (2009). Change in Contemporary English: a Grammatical Study. Cambridge: Cambridge University Press.

Nokkonen, S. (2006). The semantic variation of NEED TO in four recent British English corpora. International Journal of Corpus Linguistics I I:I, 29-7I.

Smith, N. (2003). Changes in the modals and semi-modals of strong obligation and epistemic necessity in recent British English. In Facchinetti, R., M. Krug \& F. Palmer (eds) Modality in Contemporary English. Berlin and New York: Mouton de Gruyter, 240-266.

van der Auwera, J. \& V. Plungian. (I998). Modality's semantic map. Linguistic Typology 2: 79-I 24 . 